\title{
URBANIZATION AND ECONOMIC DEVELOPMENT IN INDONESIA: DEMOGRAPHIC PERSPECTIVES ANALYSIS
}

\author{
Mustafa Elnagi Elsamani Hassan ${ }^{1}$ and Agus Joko Pitoyo ${ }^{2}$ \\ ${ }^{1}$ Department of Population and Human Studies, Faculty of Geographical and Environmental \\ Sciences, Khartoum University, Sudan, ${ }^{2}$ Faculty of Geography, Universitas Gadjah Mada, \\ Yogyakarta
}

Correspondence: Mustafa Elnagi Elsamani Hassan (e-mail: mustafa2031991@gmail.com \& mustafa2031991@uofk.edu)

\begin{abstract}
The level of urbanization has increased from $17.2 \%$ to $49.7 \%$ in the last three decades. The urbanization process in Java is occurring more dramatically and rapidly compared to that in outer Java. There is a growing trend of urbanization in the Java Islands, where the level of urbanization has increased from $11.55 \%$ to $33.64 \%$ in $1971-2010$. The ratio of urban population of all the provinces in Indonesia was greater than 20\% in 2010 exclude East Nusa Tenggara. There is a strong positive relationship between the level of regional economic development and level of urbanization. Evaluation of urbanization can be improved from two aspects: first, the forward conditions of urbanization can be analyzed, such as the number of non-farm jobs, infrastructure level and the supply capacity of public services. Second, the forward effects of urbanization should be comprehensively evaluated, including economic, social, and environmental sustainability.
\end{abstract}

Keywords: urbanization, economic development, demography

\section{Introduction}

Urbanization has been seen as an integral part of economic growth, as a defining phenomenon of the 21st century, it puts the developing world in a position of economic and demographic transformation with a complexand nuance development process. Urbanization is the massive and unprecedented historical movement of people from one rural country side to the bourgeoning cities of the world (Marmara and Usman, 2015: 2).

The historical facts and statistics reveal that almost all of the developed countries have a higher level of GDP per capita and also a higher level of urbanization. Numerous studies have previously found that the level of urbanization is closely correlated with the level of GDP per capita (Chen M. \& other, 2014). It is widely accepted that economic growth promote the expansion of industries and an increase in urban population in a country; conversely, urbanization also promotes economic growth to same extent by provide cheap labour for instance.

Urbanization is an inevitable process that occurs in tandem with economic development. The size density, and diversity of an urban population lead to innovation, the division of 
labour, and economic growth. Urbanization has positive social impact as it makes it easier to provide access to services such as education and health care. The impact of urbanization is, however, not only positive. The size of density of population and of economic activities can lead to congestion, pollution, alienation and crime. More over poverty remains a serious problem and may increase as employment in agriculture declines (Sheng and Thuzar, 2012: 67).

The debate over the role of urbanization in the Third World has culminated in two major arguments (Sukamdi, 1996). The first is the idea that urbanization is dependent on a nation's level of development and should be analysed as such. The second argument views urbanization as an independent process which either stimulates or inhibits national development (Sukamdi, 1996). Statistical evidence suggests that the richer a nation, the higher will be the level of urbanization and that urban economy generally plays an important role in overall development (World Bank, 1986; Sukamdi, 1996).

Indonesia, the largest archipelagic country in the world with more than 17,500 islands, has grown at an average annual GDP growth rate of around $5.5 \%$ since it recovered from the 1997 financial crisis. This relatively high growth has been associated with rapid urbanization and the geographical concentration of economic activities, particularly in a few major cities, such as Jakarta. In the 1990s, the proportion of urban population was below $40 \%$, but it has increased gradually and by 2012 , exceeded $50 \%$, recently is expected to be more than $50 \%$. It is thus useful to know the relationship between economic growth (Gross Regional Domestic Product GRDP) and the process of urbanization in Indonesia, since urbanization is one of the major of economic development (Sagala, Perdamen and other, 2014: 135).

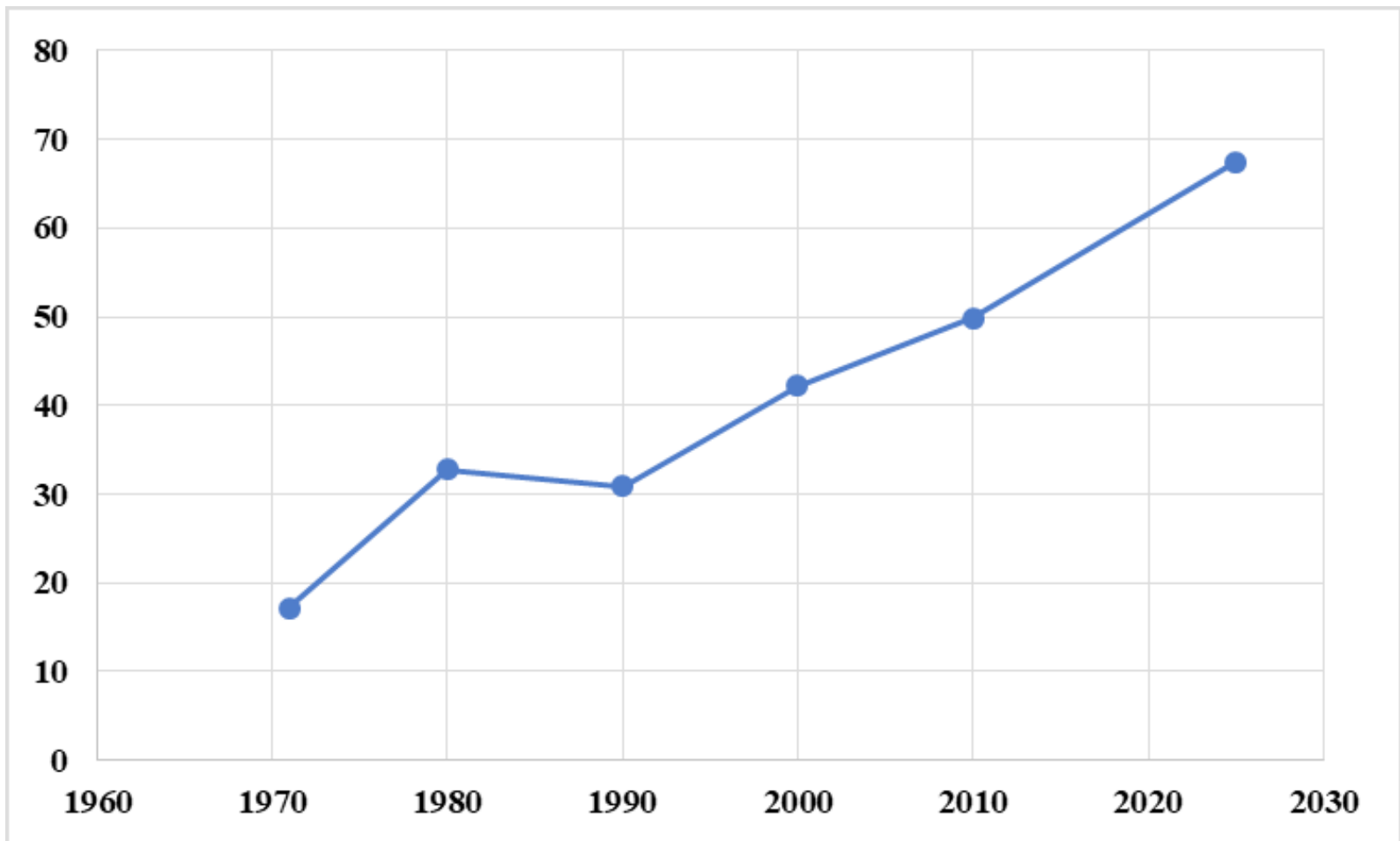

Source: Djaja Komara, 2012

Figure 1 Sharing Urban Indonesia between 1971-2025\% 


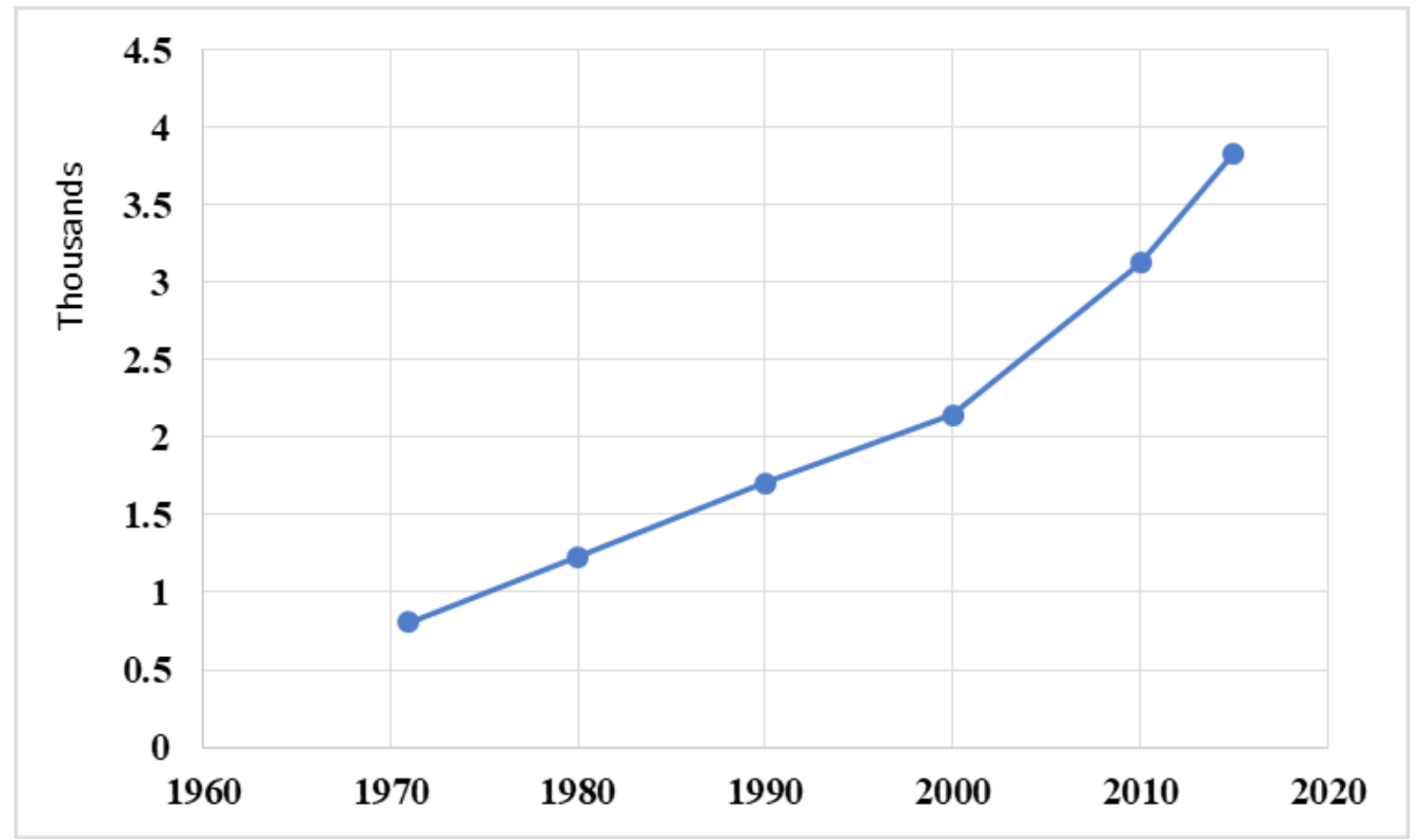

Source: World Bank data, 2017

Figure 2 GDP per Capita (constant 2010 US\$)

In Indonesia, since 1971, the development effort has produced significant results (Yulius, 1990: 1). Rapid economic growth during the 1970s brought a Indonesia into lower middle income countries by $804 \$$ in 1971 into 3.843 per capita according the constant 2010 (World Bank data, 2017). In other hand, the proportion of urban population is increased dramatically during $1971-2010$ by 20.5 millions in 1971 (17.2) into 118.3 millions in 2010 (49.8), and expected to be $67.5 \%$ by 2025 (Abd Wahab, 2015; Djaja, 2012).

\section{Data and Methods}

Urbanization began during the Industrial Revolution, and refers to the increasing number of people that live in urban areas. Urbanization is not only about a simple increase in the number of urban residents, but also involves a series change from rural to urban styles in terms of industry structure, employment, living conditions, and social public services. Economic growth is the increase in the value of goods and services produced by a country or regional economy over time. Two key indicators are selected to measure economic development level: gross domestic product (GDP) per capita, and level of urbanization measure by proportion of urban population (Chen M. \& other, 2014). The study is a contribution to the debate on the above mentioned urban economic. It attempts to verify whether there is a causal relationship between the urbanization process and economic development.

The research data come from the Central Bureau of Statistics (Badan Pusat Statistik Indonesia) publications and reports. The 
empirical data cover 33 province in Indonesia. The source of data about GRDP collected from Statistic Yearbook of Indonesia 1984, 1994, 2003, and 2015 using constant price. The number of provinces of the statistic collection periods ranging between 27 to 33 province in 1971 to 2010 . Urban population refers to people living in urban areas, as defined by national statistical offices (Badan Pusat Statistik Indonesia/ BPS). The source of the proportion of urban population is collected from the several Indonesia national censuses during 1980 to 2010. In addition, the objective of this paper is to examine the correlation difference between the level and speed of urbanization and economic growth level.

It is widely accepted that GIS and associated analytical software have played a critical role in spatial pattern analysis. The spatial analyst function was used to analyze the regional urbanization process and changes in the speed of urbanization and economic growth during 1980-2010. Moreover, to determine whether there is a correlation difference between level and speed in the relationship of urbanization and economic growth, we used the analysis methods of person correlation test, to test the mutual relationship. If the urbanization level and GDP per capita have a positive relationship, and the speed of urbanization and the economic growth rate are also positive simultaneously. In this case, it provides evidence that urbanization changes of level and speed, no doubt, in the same direction with economic growth. Thus, a positive urbanization policy would undoubtedly be supported. Otherwise, the rationale for pursuing accelerated urbanization would be weakened and would need to be reconsidered (Chen M. \& other, 2014: 2).

\section{The Patterns of Urbanization in Indonesia}

Indonesia is the third largest country in Asia after China and India. Unlike these other countries, Indonesia is an archipelago, comprised of about 13,000 island and with a total area of about 2 million square kilometers. The central government of Indonesia has divided the country into 34 provinces (See Figure 3). However, it is also customary to divide the nation according to division of water and natural resources, which leads to six major region (Sumatera, Java, Nusa Tenggara, Kalimantan, Sulawesi, and Maluku/ Papua) or alternative two major region Java and Outer Java (BPS, 2015).

As show in Figure 3, the major characteristic of Java is its high population density, that is, more than 1,000 inhabitants per square kilometers (BPS, 2015). The provinces and region of Indonesia differ not only in their social customs, language, and illiteracy rate but of the economic, the provision of public services, and utilities. As a result, they have experience different economic growth rate. This is reflected in various indicators of economic development such per capital regional domestic production, employment, life expectancy, education, etc.

Furthermore the provinces and regions of Indonesia also vary greatly in the extent to which they have become urbanized. The region pattern of urbanization and urban growth in Indonesia is presented in Table 1. This table show that among the six major groups of islands, Java is the most urbanized province since 1971 up to 2010. In 1971 the total number of urban population was $11.55 \%$ and by 2010 increase to reach $33.64 \%$ from the total number of urban population in Indonesia in 2010, with urban growth 22.13 during 1971-2010, while Maluku/Papua is the least urbanized at $0.25 \%$ in 1971 and increased into 
$0.76 \%$ by 2010 . As metropolitan region, Java contains more than $65 \%$ of Indonesia's urban population, although it has only about the $57.5 \%$ of the total population of the country. This indicates significant regional differences between Java and Outer Java (other islands). The process of urbanization in Indonesia reflects the adjustment and relocation of labour and population, not only between rural and urban area but also between regions. Such adjustment and relocation have been biased toward the major cities on Java. The higher degree of urbanization and size of urban population in Java imply that many of modern, non-agriculture activities have concentrated on Java island as well Sumatera. This raises question pertaining to causes and effects of such pattern and the impact of urbanization on development in general and economic development particularly of each region in Indonesia.

\section{Patterns and Level of Regional Urbanization in Indonesia (Provincial Level)}

A major feature of the urban growth pattern in Indonesia is its acceleration over the past three decades. Table 2 shows that absolute urban population growth was 2,250,702 persons, during 1980-1990 period, and increased to $3,111,417$ persons during 2000-2010. This implies that urban population in Indonesia in 1990 had grown approximately around 23 millions persons than 1980, and around 31 million persons during period 2000-2010. The regional patterns of urban growth is shown in Table 3. Among the regionals, urban growth was higher than national growth, from 19801990 in Aceh, West Sumatera, Riau, Jambi, Bengkulu, West Java, Yogyakarta, Bali, East Nusa Tenggara, Central Kalimantan, East Kalimantan, and Central Sulawesi.

\section{Population Density, Indonesia (Person/km sq)}
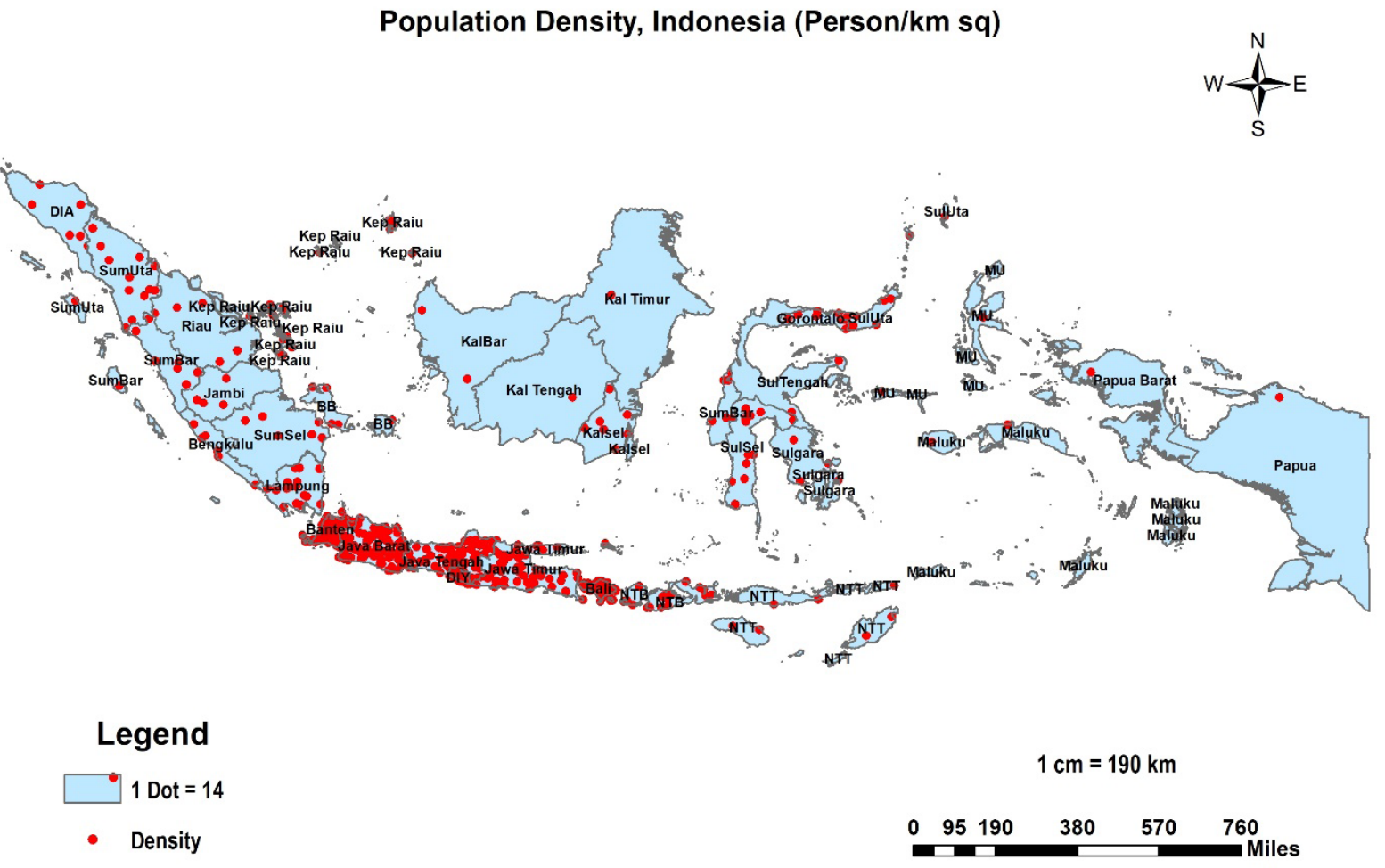

Figure 3 Population Density, Indonesia 2010 (person/ $/ \mathrm{km}^{2}$ ) 
Table 1 Percentage of Urban Population per Region to Total Percentage of Population in Indonesia and Growth Rate, 1971-2010

\begin{tabular}{cccccccccccc}
\hline Region & $\mathbf{1 9 7 1}$ & $\mathbf{\%}$ & $\mathbf{1 9 8 0}$ & $\mathbf{\%}$ & $\mathbf{1 9 9 0}$ & $\mathbf{\%}$ & $\mathbf{2 0 0 0}$ & $\mathbf{\%}$ & $\mathbf{2 0 1 0}$ & $\mathbf{\%}$ & $\begin{array}{c}\text { Growth } \\
\mathbf{1 9 7 1 -} \\
\mathbf{2 0 1 0}(\mathbf{\%})\end{array}$ \\
\hline Sumatera & 3557 & 3,01 & 5486 & 3,73 & 9313 & 5,21 & 13879 & 6,9 & 19788 & 8,33 & 5,22 \\
Java & 13675 & 11,55 & 22953 & 15,62 & 38395 & 21,49 & 59056 & 29,35 & 79950 & 33,64 & 22,13 \\
N T and Bali & 516 & 0,44 & 953 & 0,65 & 3461 & 1,94 & 3506 & 1,74 & 5126 & 2,16 & 1,72 \\
Kalimantan & 1049 & 0,89 & 1443 & 0,98 & 2511 & 1,41 & 3920 & 1,95 & 5799 & 2,44 & 1,5 \\
Sulawasi & 1373 & 1,16 & 1655 & 1,13 & 2789 & 1,56 & 4001 & 1,99 & 5843 & 2,46 & 1,28 \\
$\begin{array}{c}\text { Maluku/ } \\
\text { Papua }\end{array}$ & 295 & 0,25 & 405 & 0,28 & 750 & 0,42 & 872 & 0,43 & 1814 & 0,76 & 0,52 \\
Indonesia & 20465 & 17,29 & 32895 & 22,39 & 55442 & 31,04 & 85234 & 42,35 & 118320 & 49,79 & 32,37 \\
\hline
\end{tabular}

Source: BPS censuses reports 1971,1980, 1990, 2000, and 2010

However, urban growth in Aceh, West Sumatera, West Java, East Nusa Tenggara, Central Sulawesi, and East Kalimantan are still higher than the national rate through 2000-2010. While the urban growth was higher than national level in Sulawesi Utara, South East Sulawesi, Maluku, North Maluku, West Papua, Papua, Jambi, Lampung, Kep. Bangka Belitung, West Nusa Tenggara, West Kalimantan, Central Kalimantan, South Kalimantan, and Banten, which were not in last period.

This urban population growth was dominated by Java, where their rates of urban growth were still higher than national rate through 1980-1990 period. Java contributed around $69 \%$ and this decreased to $67 \%$ in 2000 2010 period (Table 2). Thus, the contribution of Java to total urban growth is much higher than its share to total population (less than $60 \%$ in 2010). This reveals the strength of Java's cities in attracting in-migration from outer Islands. This phenomenon has been the major concern of population distribution policies in Indonesia, and indeed, even since the colonial period.

Looking at the rate of urban growth in each province, during 1980-1990 period the rate of urban growth was substantially higher Aceh, Jambi, Bengkulu, West Jawa, DIY, Central Sulawesi, South East Sulawesi, and Maluku, and lesser in South Sumatera, Lampung, West Nusa Tenggara, West Kalimantan, South Sulawesi, and Papua. By 2000-2010 period Aceh, West Java, Banten, Central Sulawesi, South East Sulawesi, Maluku, and Papua, and lesser extent in Riau, South Sumatera, West Java, Central Java, East Java, and Gorontalo.

The attribute data relating to urbanization levels in 1971 and 2010 are put together with the regional spatial data and visualized in an GIS environment. Looking at the regional distribution of urbanization level, it is easy to see an irreversible trend of Indonesia urbanization and remarkable growth in almost all provinces during 1971-2010 (Figure 4). Nationally, the urbanization level has risen from $17.2 \%$ in 1971 to $49.79 \%$ in 2010 . In 
Table 2 Urban Growth Rate and Absolute by Province, Periods 1980-1990 and 2000-2010

\begin{tabular}{|c|c|c|c|c|}
\hline \multirow[b]{2}{*}{ Province } & \multicolumn{2}{|c|}{ Growth Rate } & \multicolumn{2}{|c|}{ Absolute/ Thousands } \\
\hline & $1980-1990$ & $2000-2010$ & $1980-1990$ & $2000-2010$ \\
\hline Nanggroe Aceh & 13 & 21 & 307 & 854 \\
\hline North Sumatera & 7 & 3 & 1,511 & 1,504 \\
\hline West Sumatera & 9 & 5 & 375 & 648 \\
\hline Riau & 8 & 0.4 & 460 & 92 \\
\hline Jambi & 14 & 4 & 250 & 267 \\
\hline South Sumatera & 4 & 1 & 570 & 307 \\
\hline Bengkulu & 23 & 2 & 168 & 72 \\
\hline Lampung & 3 & 4 & 171 & 559 \\
\hline Kep.Bangka Belitung & - & 6 & - & 215 \\
\hline Jakarta & 4 & 2 & 2161 & 1261 \\
\hline West Jawa & 11 & 6 & 6,440 & 10,314 \\
\hline Central Jawa & 6 & 2 & 2,942 & 2,312 \\
\hline Yogyakarta & 11 & 3 & 687 & 497 \\
\hline East Jawa & 6 & 3 & 3,208 & ,3613 \\
\hline Banten & - & 7 & - & 2,898 \\
\hline Bali & 10 & 5 & 371 & 775 \\
\hline West Nusa Tenggara & 5 & 4 & 199 & 545 \\
\hline East Nusa Tenggara & 8 & 5 & 167 & 300 \\
\hline West Kalimantan & 5 & 4 & 229 & 391 \\
\hline Central Kalimantan & 15 & 6 & 147 & 245 \\
\hline South Kalimantan & 6 & 4 & 263 & 445 \\
\hline East Kalimantan & 9 & 6 & 430 & 798 \\
\hline Sulawes Utara & 6 & 4 & 211 & 296 \\
\hline Central Sulawesi & 14 & 6 & 165 & 245 \\
\hline South Sulawesi & 5 & 3 & 589 & 652 \\
\hline South East Sulawesi & 16 & 7 & 142 & 242 \\
\hline Gorontalo & - & 3 & - & 53 \\
\hline Maluku & 13 & 9 & 201 & 272 \\
\hline North Maluku & - & 4 & - & 84 \\
\hline Papua & 6 & 10 & 145 & 359 \\
\hline Indonesia & 7 & 4 & 22,507 & 33,086 \\
\hline
\end{tabular}

Source: BPS censuses reports 1971,1980, 1990, 2000, and 2010 
Outer Java Islands, the urban proportion has increased rapidly from $5.74 \%$ to $16.15 \%$ over the same period. Interestingly, there is also a growing trend of urbanization in the Java Islands, where the level of urbanization has increased from $11.55 \%$ to $33.64 \%$ in 1971 2010. The color difference is clearer in the Outer Java, especially in Nusa Tenggara and Sumatera, Kalimantan, and Sulawesi which represent the bulk of the urbanization process and where urban population growth has occurred in provinces were non-urbanized yet in 1971 (Figure 4).

However, the overall relative level of distribution of urbanization on a national scale is basically changed over the time period. The Java provinces regions remain at a higher level of urbanization, while the Outer Java provinces are relatively lower. Note that most Outer Java have a distinctly higher urbanization level than Java provinces. The urban population ratio of East Kalimantan, for example, reached $62 \%$ in 2010 , which exceeds the level in the vast majority of Outer Java.

We will now interpret the changes in urbanization level in more detail, in particular their evolution over the past 39 years, using an approach of classification by different levels of urbanization. There is significant diversity in the urbanization levels, divided into ten types ranging from $0 \%$ to $100 \%$, derived from different provinces or regions.

In 1971, looking at the regional distribution of urbanization levels, it is easy to see a massive concentration of urban people between $10 \%$ and $20 \%$ and includes almost the majority of provinces of Indonesia. The second classification is in the $20-30 \%$ range, including South Kalimantan, South Sumatera, and Jambi. The third classification including only East Kalimantan, which ranging between $31 \%-40 \%$ of urban population. The extremely level of urbanization is mainly, concentrated in the Jakarta, by 100 level of urbanization.

The regional of urbanization in 2010 differs slightly from that of 1971 . This pattern of urban growth can be presented by dividing the 33 country provinces into following categories. Take a look at the regional distribution of urbanization levels, it is easy to see a massive concentration of urban population between $30 \%$ and $40 \%$ and includes almost the majority of provinces of Indonesia, such as West Sumatera, Riau, Jambi, South Sumatera, Bengkulu, West Kalimantan, Central Kalimantan, Central Sulawesi, Gorontalo, Sulawesi Barat, and North Maluku. The second category ranging between $41 \%-50 \%$, including North Sumatera, Bangka Belitung, Central Java, East Java, Bali, South Kalimantan, and North Sulawesi. The third category is ranging $51 \%-70 \%$ range, including Bali, Yogyakarta, West Java, Banten, and East Kalimantan. While the fourth category including only Riau islands, which ranging between $81 \%-90 \%$ of urban population. The extremely level of urbanization is mainly, concentrated in Jakarta, by 100 level of urbanization. Lastly, the only with urban population less than $20 \%$ is East Nusa Tenggara.

\section{The Correlation of Urbanization Level and Economic Growth}

A major indicator of economic development is Gross Domestic Product (GDP) per capita for each province. The Central Bureau of Statistic (Badan Pusat Statisik) of Indonesia estimates and publishes regional income data based on a Gross Regional Domestic Product (GRDP) at level of province. To compile there statistic, two approaches have been used: production approach and expenditure approach. The first approach is to measure value added produced 

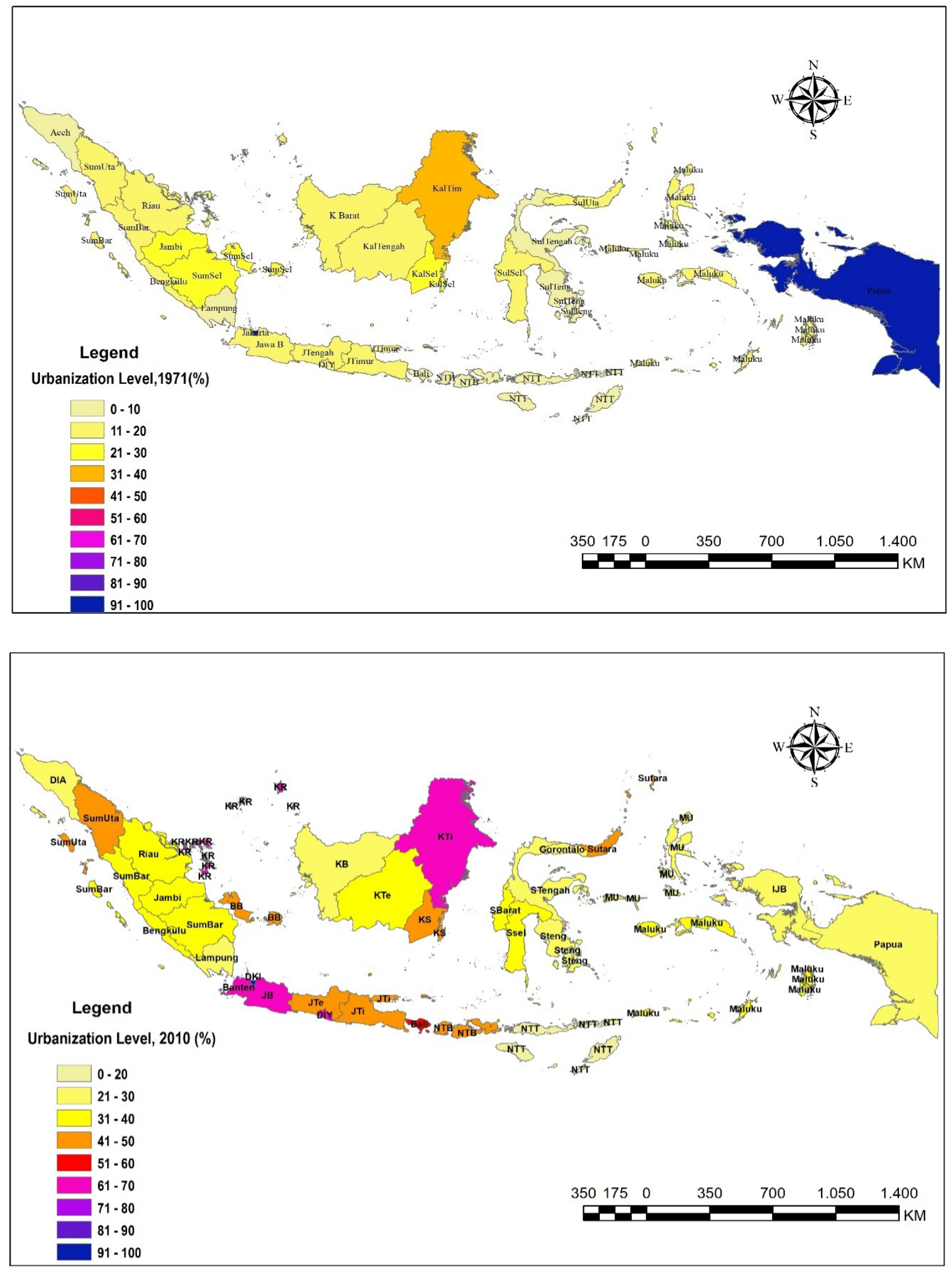

Figure 4 Regional patterns of changes in urbanization 1971-2010 
by various kinds of economic activities, while the second approach is to measure final use of country's output. In other words, GRDP is the sum of the total value added produced by all economic activities and the way using it (BPS, 2015: 263).

Addition to the possibility of bias through calculations, the estimation of regional income based on GRDP also appear to be somewhat less realistic since they do not take into account the impacts of money and commodity flows (or the regional balance of payments) between regions, on regional income. However, the GRDP per capita is not necessarily irrelevant as an independent variable affecting urbanization (Yulius, 1990: 63). Another problem is the difference of the base years of calculation between GRDPs of $1980-2010$. The former is based on 1975 constant prices while the later is based on 2010 constant prices. An attempt is therefore made to deflate the later to the level of the former in order to estimate the growth of regional GDP per capita at a comparable period of urbanization.

Table 3 shows correlation analysis between the level of urbanization and GRDP per capita. It can be seemed that most the equation shows positive relationship between the level of urbanization economic development (measured by GRDP per capita and regional variation in levels of urbanization. All correlation coefficients of the equations are highly significant at the 0.000 percent level of significance. This implies that the level of regional patterns of urbanization in Indonesia.

The results in Table 3 demonstrate that there is a strong relationship between level of urbanization and economic development, with correlation coefficients of around .87\% for 1990. This means that the variations in regional urbanization levels Indonesia can be explained by the GRDP per capita in each region. However, the foregoing generalization conceals some spatial aspects of both regional economic development and urbanization. In order to obtain a greater understanding of how and in which regions economic development affects urbanization, it will be useful to analyze the relationship between regional GDP per capita and urbanization levels using the crosstabulation technique.

The gross tabulation analysis produces some interesting features concerning the regional patterns of urbanization in relation to regional economic development in Indonesia. Data in Table 4 and 5 can be summarized as following. First, the provinces which have urbanization levels equal to and higher than the national average are regarded as the more urbanized regions. By 1980, this category comprised the provinces of Jakarta,

Table 3 The Correlation GRDP with the Level of Regional Urbanization

\begin{tabular}{cccc}
\hline Year & r Correlation & Significance & N \\
\hline 1980 & .704 & 0.000 & 26 \\
1990 & .872 & 0.000 & 26 \\
2000 & .740 & 0.000 & 31 \\
2010 & .586 & 0.000 & 33 \\
\hline
\end{tabular}

Source: Badan Pusat Statistik BPS, Censuses and Statistic Yearbook of Indonesia 
East Kalimantan, South Sumatera, Riau, Yogyakarta and North Sumatera. However, by 2010 , Jakarta, Riau Islands, Banten, West Java, Yogyakarta, Bali, and East Kalimantan were in the category. Second, the less urbanized regions are those provinces with urbanization levels ranging from $21-15 \%$ for 1980 and from $34-49 \%$ for 2010 . Finally, the provinces with urbanization levels lower than 15 and 33 (1980-2010 respectively) are present are classified as least urbanized regions.

As with urbanization, GRDP per capita should also be classified into three groups. This classification can be carried out by modifying Kaassen`s classification method (Yulius, 1990: 66). In the present study the provinces with GDP levels higher than weighted average of GRDP per capita for Indonesia as a whole are classified as the more developed regions. The provinces which have GRDP per capita lower than the national averages are classified into less developed and underdeveloped (lagging) regions. The less developed and regions are defined here as the provinces with GDP level ranging between 86-118 Rupiahs in 1980 and $1,800-28,000$ Rupiahs in 2010 . The province with GDP levels lower these lower interval limits are included the lagging regions.

Based on the above classification, crosstabulation between regional urbanization levels and the level of GRDP per capita is presented in Table 4 and 5. As shown in the main diagonal of the tables, there is a strong positive relationship between the level of regional economic development and level of urbanization. However, many provinces deviate from this generalization.

First, in the extreme cases, some provinces are classified as being more developed regions, but they are still less-urbanized or, simply put are experiencing downward deviation. There provinces include Central
Kalimantan in 1980, and Jambi, Papua, and West Papua in 2010. The reason behind the low level of urbanization in Papua and West Papua into the poor transportation network (roads, airports, stations, etc.) as well as the natural topographic limitation. It be concluded that basic industries may have less impact on urban growth when they have these characteristics. In most provinces specialized in primary products and resources-based industries have experienced economic growth faster than their rate of urbanization (Table 4 and 5). For instance, Central Kalimantan and Jambi has low level of urbanization although the level of economic development is high. This occurs because the main source of it economic growth is the export of primary product, such as timber, rattan and of other forest products. In Aceh, Lampung, West Kalimantan and Central Kalimantan, and South East Sulawesi the level of economic growth is medium, while its urbanization level is low. May resource based industries are found in this provinces such as wood processing, crumb-rubber, manufactured cement, coal and marble mining. However, the low level of urbanization due to the location of industries are not include functionally urban.

Second type of deviation is upward deviation. This is found in Yogyakarta, where the level of urbanization exceed its economic development as compared with the other provinces on the main diagonal of Table 4. There are least two possible explanation for this pattern of urbanization. One is based the history of province and another is based on the role and function of Yogyakarta in the national development plan of Indonesia. Historically, City of Yogyakarta was treated as the capital city of Kingdom Mataram before and after Dutch colonial rule. Through colonial period this city become one of the central cities of the colonial government. During the Independent 
Table 4 Gross Regional Domestic Product per Capita and Levels of Urbanization, 1980

\begin{tabular}{clll}
\hline \multirow{2}{*}{ Level of Urbanization } & \multicolumn{3}{c}{ GRDP per capita } \\
\cline { 2 - 4 } & \multicolumn{1}{c}{ High } & \multicolumn{1}{c}{ Medium } & \multicolumn{1}{c}{ Low } \\
\hline \multirow{4}{*}{ High } & Jakarta & Riau & Yogyakarta \\
& $\begin{array}{c}\text { East Kalimantan } \\
\text { South Sumatera } \\
\text { North Sumatera }\end{array}$ & & \\
& North Sulawesi & West Jawa & Central Jawa \\
& Papua & East Jawa & South Kalimantan \\
Medium & & West Kalimantan & \\
& & South Sulawesi & \\
& Central Kalimantan & Bali & Wambi \\
& & Aceh & Best Sumatera \\
& & Maluku & Lampung \\
& & & Central Sulawesi \\
& & & South East Sulawesi \\
& & & East Nusa Tenggara \\
& & West Nusa Tenggara \\
\hline
\end{tabular}

Source: Badan Pusat Statistic/BPS, Statistic Yearbook of Indonesia 1984

Table 5 Gross Regional Domestic Product per Capita and Levels of Urbanization, 2010

\begin{tabular}{|c|c|c|c|}
\hline \multirow[t]{2}{*}{ Level of urbanization } & \multicolumn{3}{|c|}{ GRDP per capita } \\
\hline & High & Medium & Low \\
\hline High & $\begin{array}{l}\text { Jakarta } \\
\text { Riau Island } \\
\text { East Kalimantan }\end{array}$ & $\begin{array}{l}\text { West Jawa } \\
\text { Banten } \\
\text { Bali } \\
\text { Yogyakarta }\end{array}$ & \\
\hline Medium & $\begin{array}{l}\text { Riau } \\
\text { Bangka Belitung } \\
\text { Islands }\end{array}$ & $\begin{array}{l}\text { North Sumatera } \\
\text { West Sumatera } \\
\text { South Sumatera } \\
\text { Jawa Central } \\
\text { East Jawa } \\
\text { South Kalimantan } \\
\text { South Sulawesi } \\
\text { North Sulawesi }\end{array}$ & $\begin{array}{l}\text { West Nusa Tenggara } \\
\text { Maluku } \\
\text { West Sulawesi }\end{array}$ \\
\hline Low & $\begin{array}{l}\text { Jambi } \\
\text { Papua } \\
\text { West Papua }\end{array}$ & $\begin{array}{l}\text { Aceh } \\
\text { Lampung } \\
\text { West Kalimantan } \\
\text { Central Kalimantan } \\
\text { South East Sulawesi }\end{array}$ & $\begin{array}{l}\text { Bengkulu } \\
\text { East Nusa Tenggara } \\
\text { Gorontalo } \\
\text { North Maluku } \\
\text { Central Sulawesi }\end{array}$ \\
\hline
\end{tabular}

Source: Badan Pusat Statistik/BPS, Statistic Yearbook of Indonesia, 2015 
revolution of Indonesia, Yogyakarta was treated as the capital city of Indonesia since Jakarta was felt to be the center of Dutch imperialism.

Therefore, historical factor played a significant role in stimulating the urbanization process of Yogyakarta. Since independence, Yogyakarta has played a significant role in national development in Indonesia. This reflection in its prevision of educational and recreation of facilities. The growth of Yogyakarta has been stimulated mainly by its high quality of educational facilities, particularly for higher education, such University of Gadjah Mada and State Institute of Islamic Studies and several private universities. In addition, Yogyakarta has also become a tourism region since the province contains various historical areas of interest. Yogyakarta received a significant number of domestic and international visitors each year. Based on the urban base theory, the educational and tourism sectors are regarded as basic activities since the inflow of people in accompanied by an inflow of money and capital. As a result, the relative position of its level of economic development is lower that its urbanization level. Additionally, it is important to note that migrants to Yogyakarta from other provinces tend to be non-productive, in the sense that contribute to population size but not to GRDP. Finally, the difficulties in estimating value added emanate from the informal sector which is the dominating the economic activities in Yogyakarta, this affect the measurement of GRDP.

\section{Conclusion}

Careful pattern exploration and correlation analysis of regional empirical data during the last three decades in Indonesia have allowed a difference to be established between level and speed, and have permitted a re-

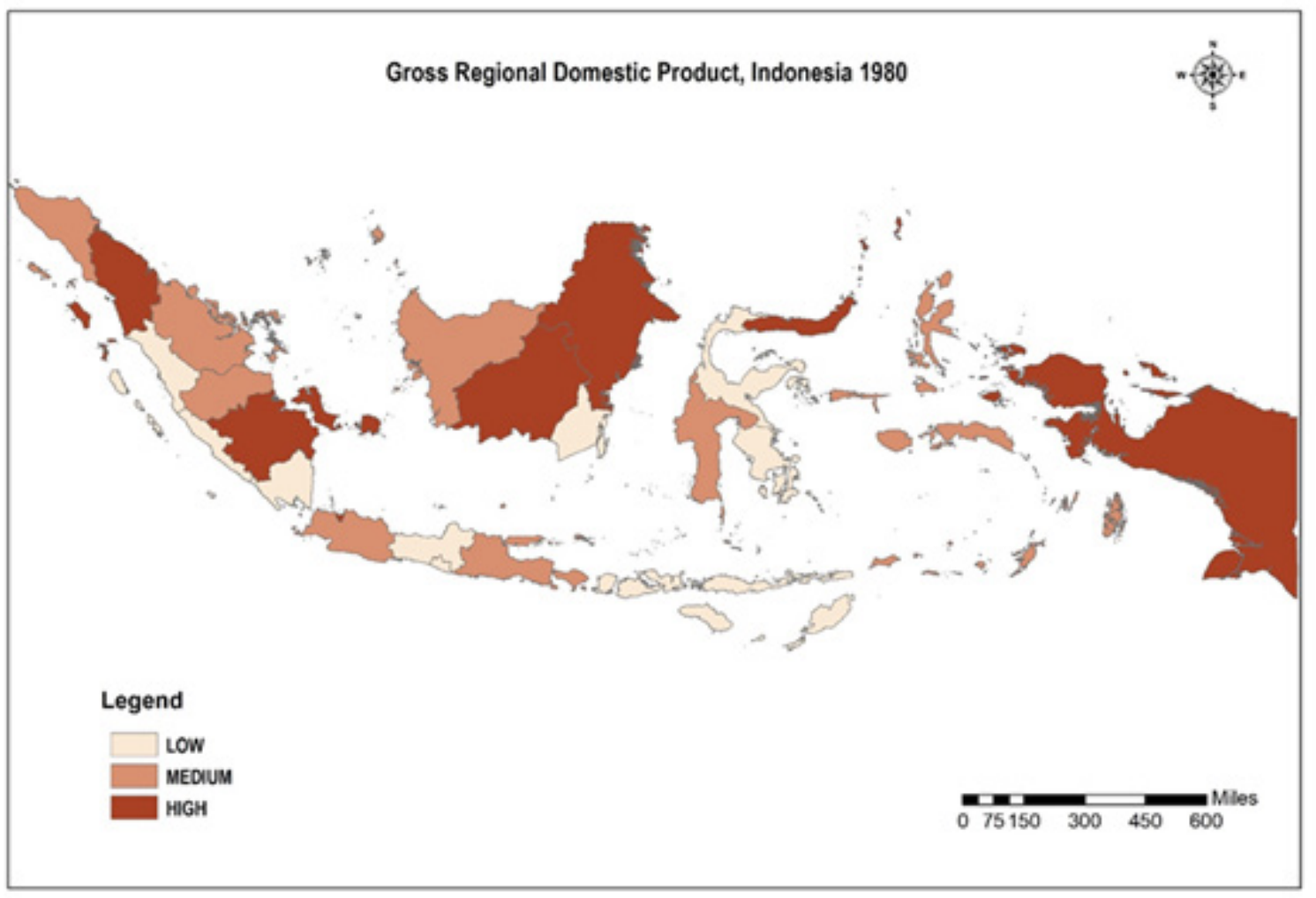

Figures 5a The regional urbanization level and gross domestic product, 1980 


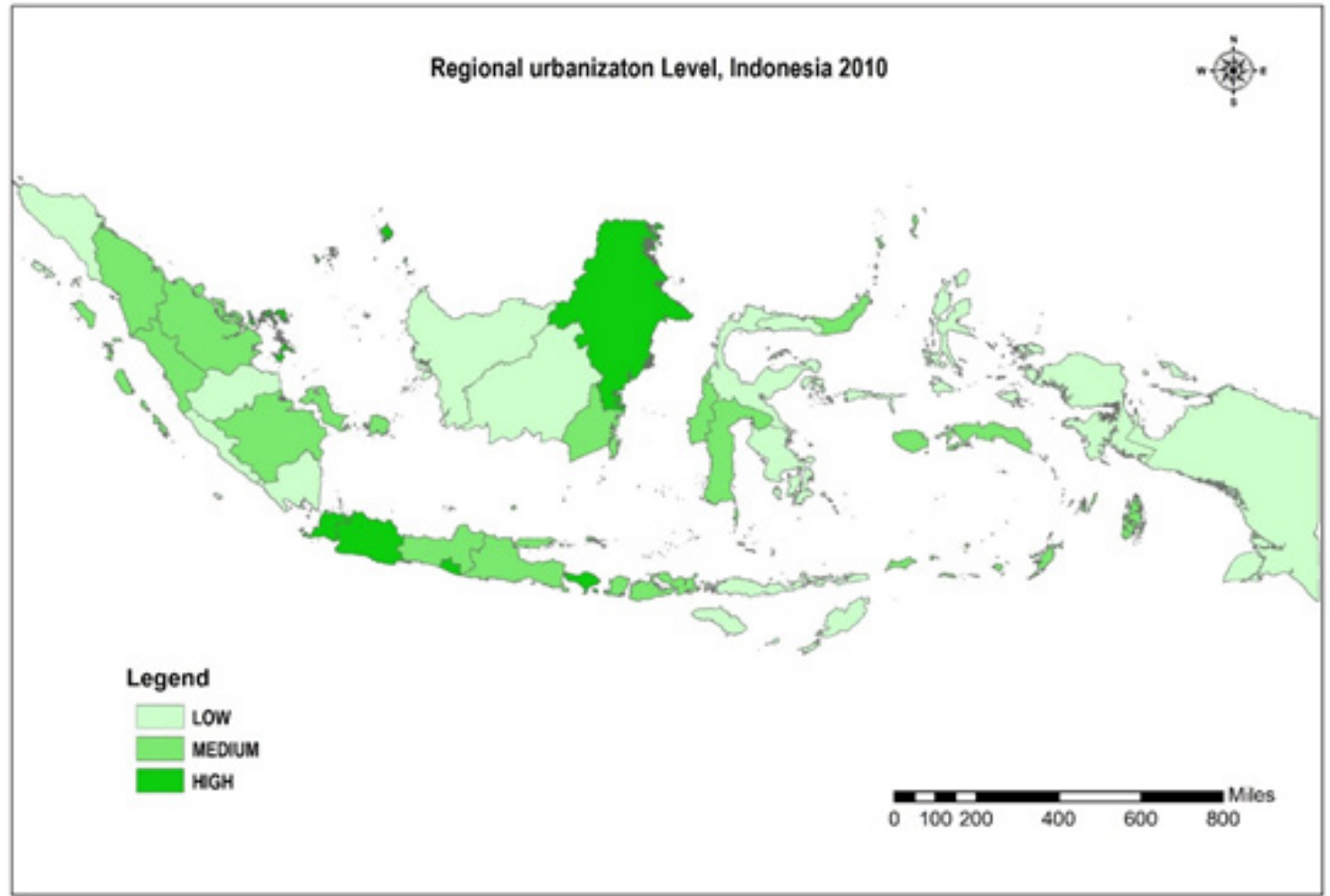

Figures 5b The regional urbanization level and gross domestic product, 2010

examination in detail of regional variation in the correlation between urbanization and economic development. A provincial level have already been selected to explore the pattern and level of urbanization and economic development. This study, however, is a one of conduct a differentiated analysis of levels and speeds of urbanization and economic development via an approach using a classification of urbanization levels on a regions scale in the period 1980-2010. The following key conclusions can be drawn and discussed.

The Indonesian has experienced an ongoing urbanizing process, and the urbanization level has increased from $17.2 \%$ to $49.7 \%$ in the last three decades. Urban center play a more important role in economic development Indonesia. The urbanization process in Java islands is occurring more dramatically and rapidly compared to that in outer Java islands. The urban proportion has increased rapidly from $5.74 \%$ to $16.15 \%$ over the same period. Interestingly, there is also a growing trend of urbanization in the Java Islands, where the level of urbanization has increased from $11.55 \%$ to $33.64 \%$ in 1971 2010. The relative patterns, however, do not change the fact that Java islands have a higher level of urbanization than outer Java regions. Moreover, the proportion of urban population of all the provinces in Indonesia was greater than $20 \%$ in 2010 excluding East Nusa Tenggara.

Similar to urbanization effect, the high urbanization level group often has high levels of GDP per capita. In general, there is a strong positive relationship between the level of regional economic development and level of urbanization. However, many provinces deviate from this generalization. First, in the extreme cases, some provinces are classified as being more developed regions but they are still less-urbanized or, simply put are 
experiencing downward deviation. There provinces include Central Kalimantan in 1980, and Jambi, Papua, and West Papua. The reason behind the low level of urbanization are the poor transportation network (roads, airports, stations, etc.), the natural topographic limitation and in most provinces specialized in primary products and resources which these location of industries are not include functionally urban. Second type of deviation is upward deviation. This is found in Yogyakarta, where the level of economic development is lower than level of urbanization. There are least two possible explanation for this pattern of urbanization. One is based the province history. Historically, the city of Yogyakarta was treated as the capital city of the kingdom Mataram before and after Dutch colonial rule. Another reason is based on the role and function of Yogyakarta in the national development plan of Indonesia. This reflection in its prevision of educational and recreation of facilities.

Further, urbanization is a complex issue that must be assessed not only in terms of urbanization speed or effects of economic growth. In order to increase the quality of the urbanization process, the forward conditions and backward effects must also be explored. It is suggested that the evaluation of urbanization can be improved from the following two aspects. First, the forward conditions of urbanization can be analyzed, such as the number of non-farm jobs, infrastructure level and the supply capacity of public services. Second, the forward effects of urbanization should be comprehensively evaluated, including economic, social, and environmental sustainability. Numerous studies have shown that urbanization has significant effects on contemporary hot topics, such as $\mathrm{CO} 2$ emissions, climate change, water resources, biodiversity, and human health
(Chen, 2015). Only when all these facets are taken into consideration can we fully assess the urbanization process. Policy-makers in developing countries should seek multiple ways of enabling forms of urbanization that contribute to economic growth, an increase in jobs, environmental sustainability, and so on, rather than pursuing accelerated urbanization.

\section{References}

Abd Wahab, Abd Wafiee. 2015. "Living in Cities: The Relationship between Urbanization and Economic Growth in Thailand versus Indonesia". In Global Majority E-Journal, 6 (2), 59-71.

Badan Pusat Statistik. 1975. Population of Indonesia: Population Census 1971. Jakarta.

1981. Population of

Indonesia: Results of Population Census 1980. Jakarta.

1991. Population of Indonesia: Results of Population Census 1990. Jakarta.

Indonesia: Results of Population Census 2000. Jakarta

2010. Population of

Indonesia: Results of Population Census 2010. Jakarta. 1984. Statistical Yearbook of Indonesia. Jakarta. p45 1994. Statistical Yearbook of Indonesia. Jakarta. p542. 2003. Statistical Yearbook of Indonesia. Jakarta. p561. 2015. Statistical Yearbook of Indonesia. Jakarta. p597.

Chen, M., Zhang, H., Liu W., Zhang, W. 2014. "The Global Pattern of Urbanization and Economic Growth: Evidence from the Last Three Decades". PloS ONE 9(8): e103799. 
doi:10.1371/journal.pone.0103799. pp 1-15.

Djaja, Komara. 2012. Urban growth and its challenges: Case of Indonesia. The World Cities Summit, Singapore.

Marmara, Abdullahi Daiyabu \& Usman, Sani Isyaku. 2015. "An Economic Analysis of Urbanization and Economic Growth in the Republic of China. SRM University, Chennai, India", accessed at http://globalbizresearch.org/Chennai_ Symposium/conference/pdf/C535 .pdf.

Sagala, Perdamen., Akita, Takahiro., and Yusuf, Arief Anshori. 2014. "Urbanization and expenditure inequality in Indonesia: Testing the Kuznets hypothesis with provincial panel data". Springer-Verlag Berlin Heidelberg. pp 133-147. accessed at https://link.springer.co m/artic le/10.1007/ s12076-013-0106-7.

Sheng, Yap Kioe., and Thuzar, Moe. 2012. Urbanization in Southeast Asia: Issues and impacts. Singapore: Institute of Southeast Asian Studies.

Sukamdi. 1996. "Urbanization and the Structure of Urban Employment in Indonesia". Sojourn: Journal of Social Issues in Southeast Asia, 11 (1), 52-75.

World Bank data. 2017. "World Bank National account data, and OECD National Accounts data files". Accessed at 14/06/17 10:00 pm.

Yulius, Yusrizal. 1990. Urbanization and Regional Economic Development in Indonesia. The Flinders University of South Australia. 